\title{
Perspektif Calon Guru Pendidikan Jasmani Terhadap Pembelajaran Online Selama Pandemi Covid-19
}

Ahmad Richard Victorian ${ }^{a}$, Silvi Aryanti ${ }^{b}$, Herri Yusfi $^{\mathrm{c}}$, Soleh Solahuddin ${ }^{\mathrm{d}}$, Wahyu Indra Bayu ${ }^{\mathrm{e} *}$

abcdeUniversitas Sriwijaya, Indonesia

Correspondence: wahyu.indra@fkip.unsri.ac.id

Received: 10 Mar 2021 Accepted: 30 Apr 2021 Published: 30 Apr 2021

\begin{abstract}
Currently, the higher education system is in a continuous process of change. There is a change paradigm in learning that is nowadays being carried out online, or what is commonly known as e-learning. The purpose of this study was to discover college students' perspective of e-learning that have been applied. An online survey with a semi-structured questionnaire was conducted on 177 (M: 112; F: 65) college students' of the Physical Education, Health and Recreation Departement, Faculty of Teacher Training, Sriwijaya University. The results show that $70.06 \%$ of students liked the application of e-learning during the Covid-19 pandemic, but on the next semester, $63.84 \%$ of students wanted face-to-face (offline) learning. This is because $67.79 \% \& 69.49 \%$ of students stated that there were lack of interaction with lecturers and classmates in the application of e-learning, although $64.41 \%$ of students think that the application of e-learning can increase their learning independency. The contradiction in the results of the study shows, only when an extraordinary event (pandemic) occurs, the application of e-learning becomes a priority to do, but if the situation returns to normal, students prefer faceto-face (offline) learning. This is because students are accustomed to practice in the field as a PE teacher candidate.
\end{abstract}

Keywords: e-learning; higher education; perspective; teacher candidate; physical education.

\begin{abstract}
Abstrak
Saat ini, sistem pendidikan tinggi sedang dalam proses perubahan yang berkelanjutan. Terdapat perubahan paradigma pembelajaran yang pada saat ini dilakukan secara online, atau yang biasa dikenal dengan e-learning. Tujuan dari penelitian ini adalah untuk mengungkap bagaimana perspektif mahasiswa terhadap pembelajaran e-learning yang sudah diterapkan. Survei dilakukan secara online dengan semi-structured questionnaire kepada 177 (L: 112; P: 65) mahasiswa Program Studi Pendidikan Jasmani, Kesehatan, dan Rekreasi, Fakultas Keguruan dan Ilmu Pendidikan, Universitas Sriwijaya. Hasil penelitian menunjukkan bahwa 70,06\% mahasiswa menyukai penerapan e-learning selama masa pandemi Covid-19, tetapi untuk semester berikutnya, 63,84\% mahasiswa menginginkan perkuliahan tatap muka. Hal ini dikarenakan $67,79 \%$ \& $69,49 \%$ mahasiswa menyatakan kurangnya interaksi dengan dosen dan teman sejawat dalam penerapan e-learning, meskipun 64,41\% mahasiswa berpendapat bahwa dengan penerapan e-learning dapat meningkatkan kemandirian belajar. Adanya kontradiksi hasil penelitian menunjukkan bahwa, hanya pada saat terjadi kejadian luar biasa (pandemi) penerapan e-learning menjadi prioritas untuk dilakukan, tetapi apabila keadaan kembali normal, mahasiswa lebih menginginkan pembelajaran tatap muka. Hal ini terjadi dikarenakan mahasiswa terbiasa melakukan praktek di lapangan sebagai calon guru Pendidikan Jasmani.
\end{abstract}

Kata kunci: calon guru; e-learning; pendidikan jasmani; pendidikan tinggi; perspektif. 


\section{Pendahuluan}

Proses pembelajaran (perkuliahan) saat ini sudah berubah, yang semula tatap muka sekarang menjadi online (Sun, Tang, \& Zuo, 2020). Lebih dari 60 juta pelajar di Indonesia (Kemdikbud, 2021a, 2021b) terdampak akibat pandemi Covid-19 yang mengakibatkan tidak adanya pembelajaran tatap muka (Firman \& Rahman, 2020). Dalam pendidikan tinggi kini terkenal dengan istilah campus at home, sehingga perkuliahan dilakukan secara virtual atau menggunakan e-learning. Saat ini e-learning menjadi kebutuhan yang penting dalam proses perkuliahan, jenis pembelajaran online seperti ini dapat dipandang sebagai perkembangan alami dari konsep pembelajaran jarak jauh (Sangrà, Vlachopoulos, \& Cabrera, 2012). Perguruan tinggi mau tidak mau menyediakan laman untuk mahasiswa dapat melakukan perkuliahan kapanpun dan dimanapun. Revolusi industri 4.0 juga mempengaruhi kemajuan teknologi dan informasi sebagai sarana pendidikan, dimana pembelajaran dapat dilakukan dan disediakan secara online. Menariknya, ada lebih banyak upaya untuk memajukan teknologi daripada mencoba memahami kebutuhan dan gaya belajar setiap pelajar dan cara belajarnya. Menggunakan $e-$ learning, peserta didik dapat mengontrol aktivitas belajarnya dengan menerapkan self-learning yang konsisten, serta mengacu pada kemampuan peserta didik dalam merencanakan, menyesuaikan, mengontrol, merefleksikan, dan mengevaluasi (Guan, 2012).

Sistem pendidikan tinggi saat ini sedang dalam proses perubahan yang berkelanjutan. Teknologi informasi dan sistem e-learning dipandang sebagai faktor penting dalam menjalankan aktivitas perguruan tinggi saat ini, institusi ini semakin banyak berinvestasi dalam sistem dan perangkat online (Popovici \& Mironov, 2015), hal ini dilakukan universitas untuk mengimbangi kebutuhan, keinginan, dan persyaratan dari mahasiswa. Namun, pada era teknologi ini, salah satu tantangan utama universitas adalah integrasi e-learning yang inovatif serta sistem untuk memperkuat dan mendukung pengajaran dan pembelajaran. El-Seoud, Taj-Eddin, Seddiek, El-Khouly \& Nosseir (2014) berpendapat bahwa pembelajaran berbasis internet secara umum dianggap sebagai pilihan atau alternatif dari pembelajaran tatap muka. Penelitian yang dilakukan oleh (Dhawan, 2020) menunjukkan bahwa e-learning menawarkan banyak manfaat bagi mahasiswa karena fleksibilitasnya dan keterpusatan pembelajaran pada mahasiswa, dan juga dapat meningkatkan interaksi antara dosen dengan mahasiswa dan juga sesama mahasiswa dengan menyiapkan metode syncronus dan asyncronus seperti email, podcast, dan video conference (Adnan \& Anwar, 2020) dan tentunya memberikan keuntungan kepada mahasiswa dalam menentukan tujuan belajar, waktu belajar, dan konten pembelajaran yang dipilih dalam pembelajaran e-learning (Suresh, Vishnu Priya, \& Gayathri, 2018). Hal ini sangat mendukung mahasiswa untuk meningkatkan proses pembelajaran selama pandemi Covid-19.

Di Amerika Serikat, ada 1,5 juta peserta didik K-12 terdaftar dalam pembelajaran online ataupun bybrid dari tahun 2009-2010 (Mohnsen, 2012). Jumlah ini mencakup pembelajaran dari kurikulum inti serta bidang konten khusus seperti musik, seni, dan pendidikan jasmani (Mohnsen, 2012). Namun, tidak semua disiplin ilmu telah sepenuhnya merangkul potensi pembelajaran online. Pendidikan jasmani, misalnya, suatu disiplin ilmu yang sebagian besar dikenal untuk pengembangan keterampilan motorik dan kompetensi gerak serta mendorong aktivitas fisik dan kebugaran jasmani, terkesan lambat dalam mengadopsi pembelajaran online. Meski lambat, ada tren program pendidikan jasmani yang menggunakan platform pembelajaran online, bahkan semakin lazim digunakan. Pada 2016, 31 negara bagian di Amerika Serikat mengizinkan kredit pendidikan jasmani diambil secara online, meningkat sembilan negara bagian dari tahun 2010 (SHAPE, 2016). Tujuh belas negara bagian yang mengizinkan pendidikan jasmani online mengharuskan disampaikan oleh pendidik jasmani bersertifikat dan enam negara bagian dilaporkan selaras dengan standar nasional (Daum \& Buschner, 2014). Model yang paling umum dari pembelajaran pendidikan jasmani online adalah metode bybrid learning, atau dapat juga disebut sebagai pembelajaran campuran (Brewer, 2001; Harris \& Metzler, 2018; Mohnsen, 2012; Mosier \& Lynn, 2012). Metode bybrid berpusat pada siswa dengan mayoritas tugas pembelajaran terjadi di luar kelas dan pertemuan tatap muka berkala untuk penilaian, instruksi, dan pedoman keselamatan (Allen \& Seaman, 2013; Harris \& Metzler, 2018; Mohnsen, 2012). Bentuk pembelajaran pendidikan 
jasmani online yang paling umum adalah materi terkait dengan kebugaran (Cardinal, 2012; Harris \& Metzler, 2018), dan memiliki tujuan utama untuk meningkatkan perilaku kesehatan dan tingkat kebugaran (Goad et al., 2021).

Penelitian saat ini dalam pembelajaran pendidikan jasmani secara online telah memberikan wawasan tentang faktor-faktor pembelajaran seperti persepsi peserta didik dan guru, peningkatan kognitif dan kebugaran siswa yang terlibat dalam pembelajaran online, dan strategi pembelajaran serta metode penyampaian pembelajaran online (Daum \& Buschner, 2014). Daum \& Buschner (2012) melakukan penelitian terhadap guru pendidikan jasmani kelas $9-12$ yang mengajar secara online $(N=32)$ untuk menyelidiki konten pembelajaran, desain instruksional, dan metode pengajaran di sekolah menengah. Temuan utama mengungkapkan kurangnya perkembangan keterampilan motorik dan partisipasi siswa yang terbatas, dan kurang dari 30\% guru menunjukkan memenuhi 225 menit pendidikan jasmani yang direkomendasikan. Dan ditemukan juga bahwa pembelajaran blended yang memadukan pembelajaran online dengan tradisional (tatap muka) memberikan persepsi positif kepada peserta didik tingkat SMA (Williams, Martinasek, Carone, \& Sanders, 2020).

Beberapa penelitian menunjukkan bahwa program pelatihan pendidikan jasmani sedang berjuang untuk secara efektif memperkenalkan dan memodelkan praktik terbaik pengintegrasian pendidikan jasmani dengan teknologi (Gibbone \& Mercier, 2014; Juniu, 2011). Pelatihan guru yang akan membahas teknologi dalam pendidikan jasmani, Williams (2013) menyarankan bahwa calon guru tidak cukup siap untuk menerjemahkan materi pembelajaran dalam lingkungan online dan dengan demikian diperlukan pelatihan yang terkait dengan pembelajaran pendidikan jasmani secara online. Hasil dari survei nasional di Amerika Serikat yang menargetkan upaya program pendidikan guru untuk mempersiapkan guru pra-jabatan dalam pendidikan online menunjukkan bahwa 1,3\% $(\mathrm{n}=522)$ memiliki pengalaman lapangan untuk guru pra-jabatan dalam pendidikan online, sementara 13\% tambahan menunjukkan kesesuaian dengan rencana saat ini untuk mengintegrasikan pengalaman lapangan secara virtual (Kennedy \& Archambault, 2012).

Namun, pada saat menggunakan e-learning ada beberapa aspek yang harus diperhatikan untuk mengurangi kendala dalam proses belajar mahasiswa, seperti penurunan motivasi, delay feedback yang diberikan oleh dosen, atau bahkan perasaan terisolasi karena kurangnya kehadiran fisik teman sekelas (Yusuf \& Al-Banawi, 2013). Meskipun begitu, hambatan ini dapat diatasi dengan bantuan dosen yang harus menyesuaikan strategi pengajaran mereka untuk memenuhi kebutuhan mahasiswa. Untuk melakukannya, pengalaman dan pengetahuan tentang mengajar e-learning diperlukan. Kontradiksi dengan survei awal yang menunjukkan bahwa 73,33\% dosen yang mengajar pada program studi Pendidikan Jasmani, Kesehatan, dan Rekreasi, FKIP, Universitas Sriwijaya menggunakan platform online untuk mengajar untuk pertama kali. Hal ini juga ditambah dengan kurangnya pengalaman dosen dalam menggunakan e-learning dan karena waktu yang singkat dimana harus beradaptasi dengan gaya mengajar pada kondisi yang baru. Dengan demikian, disimpulkan bahwa mahasiswa dan dosen belum siap untuk mendapatkan pengalaman online sepenuhnya. Meskipun ada beberapa hambatan dan tantangan yang harus diperbaiki selama proses pembelajaran menggunakan e-learning.

Dosen dan mahasiswa dalam menjalankan pembelajaran berbasis e-learning menghadapi banyak tantangan. Hal ini dapat terlihat dari mereka harus menyeimbangkan kesehatannya dikarenakan harus duduk berjam-jam di depan komputer/laptop untuk melakukan pembelajaran dan aktivitas digital lainnya, serta menyeimbangkan emosionalnya karena menghadapi pola pembelajaran yang berbeda, sehingga harus mendapatkan motivasi lebih dari lingkungan sekitarnya, dan juga harus dipertimbangkan fakta bahwa kurangnya aksesibilitas, konektivitas, dan perangkat yang sesuai, serta masalah sosial yang diwakili oleh kurangnya komunikasi dan interaksi dengan guru dan teman sebaya (Aboagye, Yawson, \& Appiah, 2021) merupakan tantangan nyata yang harus dihadapi selama pembelajaran menggunakan e-learning. 
Mempertimbangkan aspek-aspek yang dijelaskan di atas, dapat dinyatakan bahwa telah terjadi transisi luar biasa dalam pembelajaran. Sehingga penerapan e-learning memberikan dampak nyata terhadap paradigma proses pembelajaran dan perspektif mahasiswa terhadap pembelajaran tersebut. Hal tersebut penting, relevan, dan perlu untuk dianalisis apakah mahasiswa telah beradaptasi pada e-learning dan apakah mereka puas atau tidak puas dengan pengalaman online ini. Pergeseran paradigma pembelajaran dari tatap muka menjadi tatap maya ini dapat memunculkan perubahan perspektif mahasiswa dalam hal pembelajaran dan perspektif mereka mungkin berbeda dari yang ditemukan dalam studi sebelumnya selama pandemi Covid-19. Untuk itu, tujuan dari penelitian ini adalah untuk mengungkap bagaimana perspektif mahasiswa terhadap pembelajaran $e$-learning yang sudah diterapkan selama ini.

\section{Metode Penelitian}

Penelitian ini merupakan penelitian survei dengan menggunakan non-structural questionnaire yang telah disiapkan untuk diisi oleh subjek penelitian. 11 pernyataan disusun pada angket penelitian ini untuk menjawab hipotesis berikut ini: (1) mahasiswa akan menunjukkan preferensi terhadap aktivitas online dibandingkan dengan metode pembelajaran tradisional; dan (2) mahasiswa akan menunjukkan perbedaan sikap terhadap e-learning berdasarkan angkatan mahasiswa. Mahasiswa diminta memilih salah satu jawaban (Sangat Setuju $=4$ poin, Setuju $=3$ poin, Tidak Setuju $=2$ poin, Sangat Tidak Setuju $=1$ poin) untuk masing-masing pernyataan. Dengan 11 pernyataan tersebut, peneliti mencoba menggambarkan tiga hal; (1) gambaran mahasiswa terhadap penerapan e-learning (preferensi, interaksi dengan teman satu kelas dan dosen); (2) gambaran mahasiswa terhadap nilai yang didapatkan selama mengikuti e-learning (proses dan penilaian akhir); dan (3) gambaran motivasi mahasiswa terhadap penggunaan e-learning. Serta satu pertanyaan untuk mengetahui aplikasi video conference yang digunakan untuk proses perkuliahan.

\section{Tabel 1. Pertanyaan pada Kuesioner yang Digunakan}

\begin{tabular}{|c|c|}
\hline No. & Pertanyaan/Pernyataan \\
\hline 1 & Saya suka menggunakan e-learning untuk perkuliahan pada semester ini \\
\hline 2 & $\begin{array}{l}\text { Saya merasa penerapan e-learning oleh dosen dalam mengajar pada semester ini membantu saya } \\
\text { meningkatkan keterampilan saya dalam olahraga }\end{array}$ \\
\hline 3 & It saya penerapan e-learning yang dilakukan dosen dalam perkuliahan semester ini tidak berguna \\
\hline 4 & Ingkat dengan menggunakan e-learning untuk perkuliahan pada semester \\
\hline 5 & Saya berharap dosen prodi Penjaskesrek terus menggunakan e-learning dalam pengajarannya \\
\hline 6 & s lebih menarik daripada metode \\
\hline 7 & E-lea \\
\hline 8 & kat \\
\hline 9 & lengan teman sekelas saya \\
\hline 10 & $\begin{array}{l}\text { Menggunakan e-learning untuk perkuliahan, mendorong saya untuk terus belajar mandiri melalui } \\
\text { internet }\end{array}$ \\
\hline 11 & ak ingin melaksanakan kuliah dengan menggunakan e-learning \\
\hline
\end{tabular}

Purposive accidental sampling diterapkan untuk memperoleh data penelitian dengan subjek penelitian adalah mahasiswa S1 Program Studi Pendidikan Jasmani, Kesehatan dan Rekreasi, FKIP, Universitas Sriwijaya dengan jumlah total mahasiswa yang terdaftar/aktif adalah 347 mahasiswa berdasarkan data dari kemahasiswaan. Data dikumpulkan secara online. Kuisioner dikirimkan sebagai link melalui google form dengan link https://forms.gle/5274ZQmoCnPYJNP48 yang dilakukan pada bulan Februari 2021. Para partisipan dalam penelitian ini menerima informasi di awal kuesioner tentang tujuan survei dan persetujuan informasi. Memberikan penilaian sesuai dengan keadaan sebenarnya, dan mereka menyetujui partisipasi dalam penelitian ini. Alamat email tidak dikumpulkan untuk menghormati 
anonimitas dan kerahasiaan. Rata-rata waktu yang dibutuhkan untuk menjawab kuesioner adalah 5 menit. Data yang diperoleh melalui pengisian google form dilakukan penyaringan berdasarkan: (1) pengisian identitas yang sesuai dengan data kemahasiswaan; (2) mahasiswa sasaran adalah sasaran adalah angkatan tahun 2018-2020; dan (3) tidak ada responden yang hanya menjawab pada satu variabel jawaban saja. Hasil dari penyaringan data penelitian tampak pada tabel 1 di bawah ini:

\section{Tabel 2. Demografi Subjek Penelitian}

\begin{tabular}{ccccccc}
\hline \multirow{2}{*}{ Kategori Subjek Penelitian } & \multicolumn{3}{c}{ Angkatan } & \multirow{2}{*}{ Jumlah } & \multirow{2}{*}{ Persentase } \\
\cline { 3 - 5 } & & $\mathbf{2 0 1 8}$ & $\mathbf{2 0 1 9}$ & $\mathbf{2 0 2 0}$ & & \\
\hline Jenis & Laki-Laki & 32 & 26 & 54 & 112 & $63,28 \%$ \\
Kelamin & Perempuan & 8 & 21 & 36 & 65 & $36,72 \%$ \\
\hline \multicolumn{2}{r}{} & Total & & & $\mathbf{1 7 7}$ & $\mathbf{1 0 0 \%}$ \\
\hline
\end{tabular}

\section{Hasil}

Satu tahun sejak Maret 2020, Universitas Sriwijaya telah melaksanakan perkuliahan jarak jauh karena Pandemi Covid-19. Pada awalnya penerapan pembelajaran jarak jauh menggunakan berbagai platform yang tersedia seperti google classroom, schoology, edmodo, dan virtual conference (zoom, google meet, BigBlue Button, etc) yang tersedia gratis. Sejak tahun akademik 2020/2021, Universitas Sriwijaya telah membuat laman e-learning untuk mengakomodir pelaksanaan perkuliahan jarak jauh bagi mahasiswa Universitas Sriwijaya yang dapat diakses pada laman elearning.unsri.ac.id. Berikut hasil survei yang terangkum dalam grafik dan tabel di bawah ini:

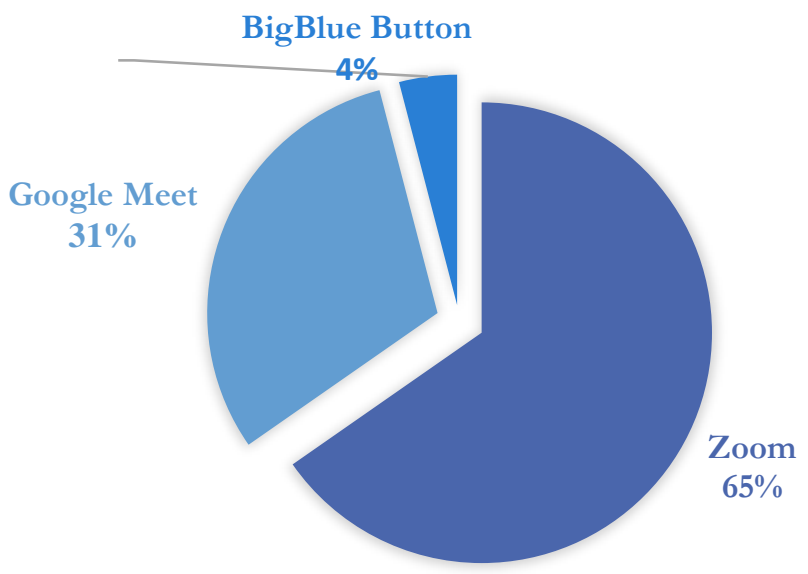

\section{Gambar 1. Aplikasi Video Conference yang Digunakan untuk Proses Perkuliahan}

Gambar 1 menunjukkan bahwa aplikasi Zoom Meeting adalah aplikasi yang paling sering digunakan oleh dosen dan mahasiswa dalam melakukan video conference dalam perkuliahan. Aplikasi ini memang sedang naik daun di tengah pandemi Covid-19, karena dengan aplikasi ini kita tetap dapat terhubung dengan banyak orang dalam satu waktu. Meskipun versi gratis hanya terbatas 40 menit durasi yang diberikan, tetapi mahasiswa dan dosen tetap berusaha mendapatkan versi education yang diberikan secara gratis oleh zoom.us sebagai bagian dari dukungan selama pandemi Covid-19. Menyusul aplikasi google meet yang secara otomatis tersedia apabila kita mempunya email dengan afiliasi google. Seluruh dosen di Universitas Sriwijaya telah mempunya email tersebut, sehingga tidak perlu lagi "membeli" akun untuk dapat menggunakan aplikasi google meet. Dan yang terakhir adalah aplikasi BigBlue Button yang tersemat dalam e-learning Unsri, sehingga hasil rekaman dapat tersedia langsung dalam e-learning Unsri. Aplikasi ini tidak menjadi favorit oleh dosen dan mahasiswa karena terbatasnya server yang dimiliki oleh Unsri, sehingga 
apabila menggunakan aplikasi BigBlue Button pada weekday sering terjadi permasalahan dalam jaringan dan koneksi.

Tabel 2. Distribusi Frekuensi dari Indikator Perspektif Mahasiswa Terkait e-Learning

\begin{tabular}{|c|c|c|c|c|}
\hline Pertanyaan & $\begin{array}{l}\text { Sangat } \\
\text { Setuju }\end{array}$ & Setuju & $\begin{array}{c}\text { Kurang } \\
\text { Setuju }\end{array}$ & $\begin{array}{l}\text { Tidak } \\
\text { Setuju }\end{array}$ \\
\hline $\begin{array}{l}\text { Saya suka menggunakan e-learning untuk perkuliahan pada } \\
\text { semester ini }\end{array}$ & $22,60 \%$ & $47,46 \%$ & $19,77 \%$ & $10,17 \%$ \\
\hline $\begin{array}{l}\text { Saya merasa penerapan e-learning oleh dosen dalam } \\
\text { mengajar pada semester ini membantu saya meningkatkan } \\
\text { keterampilan saya dalam olahraga }\end{array}$ & $17,51 \%$ & $36,72 \%$ & $33,33 \%$ & $12,43 \%$ \\
\hline $\begin{array}{l}\text { Menurut saya penerapan e-learning yang dilakukan dosen } \\
\text { dalam perkuliahan semester ini tidak berguna }\end{array}$ & $5,65 \%$ & $16,38 \%$ & $37,29 \%$ & $40,68 \%$ \\
\hline $\begin{array}{l}\text { Saya pikir nilai saya akan meningkat dengan menggunakan } \\
\text { e-learning untuk perkuliahan pada semester ini }\end{array}$ & $31,64 \%$ & $47,46 \%$ & $16,95 \%$ & $3,95 \%$ \\
\hline $\begin{array}{l}\text { Saya berharap dosen Prodi Penjaskesrek terus } \\
\text { menggunakan e-learning dalam pengajarannya }\end{array}$ & $20,34 \%$ & $33,33 \%$ & $24,29 \%$ & $22,03 \%$ \\
\hline $\begin{array}{l}\text { Menggunakan e-learning untuk perkuliahan pada Prodi } \\
\text { Penjaskesrek lebih menarik daripada metode tradisional } \\
\text { (tatap muka) }\end{array}$ & $13,56 \%$ & $11,86 \%$ & $28,81 \%$ & $45,76 \%$ \\
\hline E-learning membuat saya lebih tertarik untuk belajar & $14,69 \%$ & $23,16 \%$ & $41,24 \%$ & $20,90 \%$ \\
\hline $\begin{array}{l}\text { Dengan menggunakan e-learning untuk perkuliahan, } \\
\text { peluang interaksi dengan dosen akan meningkat }\end{array}$ & $13,56 \%$ & $18,64 \%$ & $41,24 \%$ & $26,55 \%$ \\
\hline $\begin{array}{l}\text { Dengan menggunakan e-learning untuk perkuliahan, } \\
\text { peluang interaksi dengan teman sekelas saya meningkat }\end{array}$ & $11,86 \%$ & $18,64 \%$ & $35,59 \%$ & $33,90 \%$ \\
\hline $\begin{array}{l}\text { Menggunakan e-learning untuk perkuliahan, mendorong } \\
\text { saya untuk terus belajar mandiri melalui internet }\end{array}$ & $28,25 \%$ & $36,16 \%$ & $24,29 \%$ & $11,30 \%$ \\
\hline $\begin{array}{l}\text { Saya tidak ingin melaksanakan kuliah dengan } \\
\text { menggunakan e-learning }\end{array}$ & $24,29 \%$ & $39,55 \%$ & $20,90 \%$ & $15,25 \%$ \\
\hline
\end{tabular}

Perkuliahan mahasiswa Prodi Penjaskesrek, FKIP, Universitas Sriwijaya menggunakan e-learning memiliki kelebihan dan kekurangan. Kelebihan dalam penggunaan $e$-learning dari perspektif mahasiswa berdasarkan hasil penelitian diperoleh persentase sebesar 70,06\% yang artinya mahasiswa menyukai penggunaan e-learning saat perkuliahan jarak jauh diterapkan, 64,41\% mahasiswa juga berpandangan bahwa dengan penerapan e-learning dapat meningkatkan kemandirian belajar. Sedangkan kekurangan dari penerapan e-learning menurut perspektif mahasiswa adalah kurangnya interaksi yang terjadi selama proses pembelajaran baik itu antara dosen dengan mahasiswa maupun antara teman satu kelas $(67,79 \%$ dan 69,49\%). Meskipun begitu, ada kontradiksi dari hasil penelitian ini. Dalam penelitian ini menunjukkan bahwa hanya pada saat terjadi kejadian luar biasa (pandemi) penerapan $e$-learning menjadi prioritas untuk dilakukan, tetapi apabila keadaan kembali normal (new normal), mahasiswa lebih menginginkan perkuliahan secara tatap muka, hal ini ditunjukkan dengan 63,84\% mahasiswa menginginkan perkuliahan tatap muka untuk semester berikutnya. 
Tabel 3. Data Hasil Penelitian Penggunaan e-Learning Mahasiswa

\begin{tabular}{|c|c|c|c|c|c|c|c|c|c|c|}
\hline \multirow{3}{*}{ Variabel } & \multirow{3}{*}{ Pernyataan } & \multicolumn{8}{|c|}{ Angkatan } & \multirow[b]{3}{*}{$\%$} \\
\hline & & \multicolumn{2}{|c|}{2018} & \multirow[b]{2}{*}{$\%$} & \multicolumn{2}{|c|}{2019} & \multirow[b]{2}{*}{$\%$} & \multicolumn{2}{|c|}{2020} & \\
\hline & & $\begin{array}{c}\text { Skor } \\
\text { Hasil }\end{array}$ & $\begin{array}{l}\text { Skor } \\
\text { Maks }\end{array}$ & & $\begin{array}{l}\text { Skor } \\
\text { Hasil }\end{array}$ & $\begin{array}{l}\text { Skor } \\
\text { Maks }\end{array}$ & & $\begin{array}{l}\text { Skor } \\
\text { Hasil }\end{array}$ & $\begin{array}{l}\text { Skor } \\
\text { Maks }\end{array}$ & \\
\hline \multirow{2}{*}{$\begin{array}{c}\text { Preferensi } \\
\text { dan }\end{array}$} & P1 & 110 & 160 & $68,75 \%$ & 109 & 160 & $68,13 \%$ & 116 & 160 & $72,50 \%$ \\
\hline & P8 & 80 & 160 & $50,00 \%$ & 83 & 160 & $51,88 \%$ & 99 & 160 & $61,88 \%$ \\
\hline \multirow[t]{2}{*}{ Interaksi } & P9 & 82 & 160 & $51,25 \%$ & 78 & 160 & $48,75 \%$ & 87 & 160 & $54,38 \%$ \\
\hline & P3 & 119 & 160 & $74,38 \%$ & 119 & 160 & $74,38 \%$ & 134 & 160 & $83,75 \%$ \\
\hline \multirow{3}{*}{$\begin{array}{c}\text { Proses } \\
\text { dan } \\
\text { Penilaian }\end{array}$} & P4 & 113 & 160 & $70,63 \%$ & 126 & 160 & $78,75 \%$ & 132 & 160 & $82,50 \%$ \\
\hline & P5 & 93 & 160 & $58,13 \%$ & 87 & 160 & $54,38 \%$ & 116 & 160 & $72,50 \%$ \\
\hline & P6 & 74 & 160 & $46,25 \%$ & 63 & 160 & $39,38 \%$ & 97 & 160 & $60,63 \%$ \\
\hline \multirow{4}{*}{ Motivasi } & P2 & 87 & 160 & $54,38 \%$ & 80 & 160 & $50,00 \%$ & 104 & 160 & $65,00 \%$ \\
\hline & P7 & 97 & 160 & $60,63 \%$ & 96 & 160 & $60,00 \%$ & 114 & 160 & $71,25 \%$ \\
\hline & P10 & 103 & 160 & $64,38 \%$ & 108 & 160 & $67,50 \%$ & 128 & 160 & $80,00 \%$ \\
\hline & P11 & 93 & 160 & $58,13 \%$ & 100 & 160 & $62,50 \%$ & 80 & 160 & $50,00 \%$ \\
\hline
\end{tabular}

Tabel 3 menunjukkan perspektif calon guru pendidikan jasmani terhadap pembelajaran online yang sudah diterapkan sangatlah terbuka dan menerima kondisi yang ada. Artinya bahwa pembelajaran dengan menerapkan e-learning pada masa pandemi Covid-19 adalah solusi yang tepat untuk dilakukan.

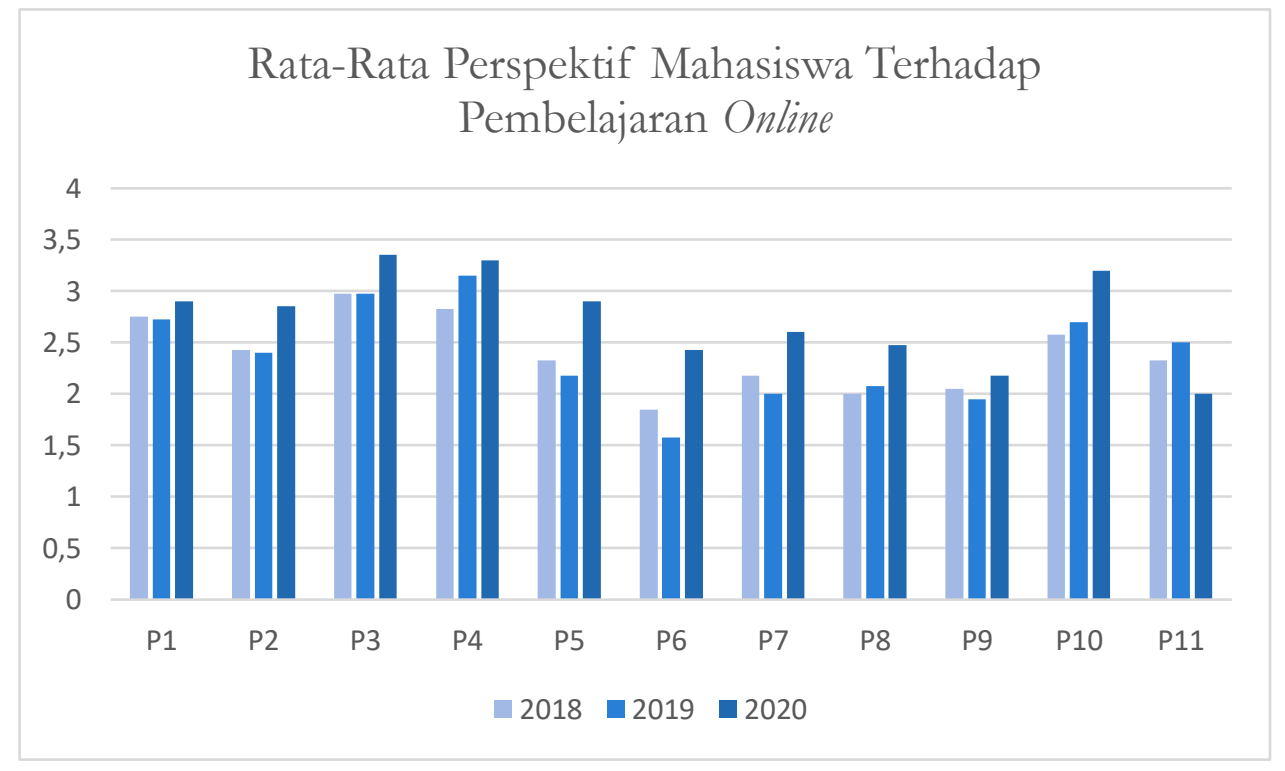

\section{Gambar 2. Perspektif Mahasiswa Terhadap Pembelajaran Online Berdasarkan Angkatan}

Gambar 2 menunjukkan bahwa Angkatan 2020 lebih tinggi perspektif terhadap pembelajaran online kecuali pada pernyataan ke 11 bahwa Angkatan 2020 lebih menginginkan pembelajaran dilakukan secara online daripada tatap muka pada semester berikutnya. Hal ini terjadi karena angkatan 2020 mulai mengikuti pembelajaran pada pendidikan tinggi langsung diterapkan pembelajaran secara online, sehingga masih beranggapan bahwa pembelajaran online lebih baik daripada pembelajaran tatap muka.

\section{Pembahasan}

Menciptakan pengalaman e-learning yang sesuai untuk pendidikan jasmani memiliki tantangan tersendiri. Hal ini dikarenakan banyak dosen yang percaya bahwa perkuliahan online tidak akan efektif tanpa perkuliahan tatap muka yang saling berintegrasi dengan e-learning. Dosen juga percaya bahwa perkuliahan tatap muka adalah satu-satunya cara untuk menilai hasil belajar mahasiswa. Dan juga 
layanan internet yang belum terjangkau untuk semua mahasiswa, sehingga tidak semua mahasiswa dapat mengakses e-learning (Indrayana \& Sadikin, 2020). Keterampilan teknis dosen dapat direpresentasikan dengan kemampuannya dalam menggunakan berbagai fungsi yang ditawarkan oleh e-learning untuk dapat menyesuaikan dengan kondisi mengajar mereka serta, misalnya, menggunakan fungsi konferensi video di mana mahasiswa dapat berpartisipasi secara aktif karena dosen memiliki kemungkinan untuk menjadikan mereka moderator. Keterampilan teknis ini terdiri dari kemampuan untuk mempresentasikan materi perkuliahan melalui berbagi layar, menggunakan obrolan secara langsung selama presentasi, menawarkan mahasiswa untuk bekerja dalam tim selama presentasi, mengunggah berbagai tautan di e-learning dengan mengacu pada berbagai sumber informasi, sampai dengan membuat video pendek untuk praktek/unjuk kerja tertentu dan mempostingnya di platform elearning.

Salah satu implikasi dari diterapkannya e-learning adalah untuk dapat membantu dosen dan mahasiswa dalam pembelajaran sehingga kompetensi mahasiswa dapat ditingkatkan di bidang teknologi. Dosen dan mahasiswa dapat berinteraksi melalui forum diskusi, video conference seperti bigblue botton, zoom meeting, google meet, skeype, atau semacamnya, dan mahasiswa dapat mengakses materi sewaktu-waktu dan berulang-ulang sehingga dapat mempelajari lebih dalam. Hal ini sejalan dengan hasil penelitian (Saifuddin, 2018) yang menganalisis penggunaan e-learning menurut pengertian mahasiswa bahwa mempunyai aksesibilitas yang tinggi yaitu diperoleh persentase sebesar $91 \%$, dengan penggunaan ringan $83 \%$. Tentunya membuat persepsi baik untuk mahasiswa yang diberikan peran lebih besar dalam pelaksanaan pembelajaran dengan pola blended learning sebagai bentuk pembelajaran yang dikolaborasikan antara e-learning dengan tatap muka. Hal ini juga didukung oleh penelitian terdahulu yang menjelaskan bahwa dari hasil penelitiannya dikatakan bahwa mahasiswa antusias dalam penggunaan e-learning sebagai bagian dari proses pembelajaran dan juga membuat mahasiswa menjadi mandiri dan memiliki keberanian dalam mengemukakan pendapat (Indrayana \& Sadikin, 2020; Yodha, Abidin, \& Adi, 2019).

Dalam pendidikan tinggi, penting bagi dosen untuk mengingat bahwa sebagian besar aktivitas fisik menggunakan pembelajaran dan penilaian di dalam kelas (tatap muka). Dosen ingin memantau aktivitas dan memberikan pengetahuan secara langsung. Penggunaan internet untuk mendukung pembelajaran jarak jauh adalah alat yang ideal untuk melengkapi proses perkuliahan. Sedangkan kualitas proses pendidikan dalam perkuliahan online bergantung pada beberapa faktor, di antaranya adalah: tingkat pelatihan yang dimiliki dosen dalam menggunakan teknologi, gaya mengajar, interaksi dengan mahasiswa, strategi yang digunakan untuk menarik perhatian mahasiswa, mendorong interaksi anta mahasiswa, penerapan pembelajaran kolaboratif, umpan balik yang cepat, mendorong mahasiswa untuk mengalokasikan lebih banyak waktu untuk menyelesaikan tugas, memotivasi mahasiswa, pembelajaran yang beragam, dan penerapan teknologi dalam proses perkuliahan (Cheung \& Cable, 2017).

Hasil penelitian ini juga sejalan dengan penelitian lain (Galy, Downey, \& Johnson, 2011; Tagoe, 2012) yang menyarankan bahwa mahasiswa menganggap bahwa proses pembelajaran online tidak menunjukkan nilai yang positif daripada proses pembelajaran tatap muka/tradisional, mereka lebih memilih penggunaan platform e-learning yang dikombinasikan dengan pembelajaran tradisional/tatap muka. Dalam e-learning ada yang disebut pembelajaran syncronus dan asyncronus. Untuk pembelajaran syncronus, dosen dapat menggunakan video conference dalam melakukan perkuliahan. Sedangkan untuk pembelajaran asyncronus dapat menggunakan aplikasi pembelajaran yang sudah tersedia, membaca materi secara online, kelompok diskusi, email, dan website yang sudah mendapat persetujuan oleh dosen (Mohnsen, 2012). Dan juga mahasiswa dapat diberikan waktu ekstra untuk melakukan aktivitas fisik agar tetap aktif setelah kelas berakhir (Mooneyhan, 2012). Karena penggunaan e-learning yang tepat memungkinkan lebih banyak waktu dialihkan untuk aktivitas fisik.

Penerapan e-learning memberikan dampak kepada pendidik yang dihadapkan dapat membangun 
interaksi secara dinamis tidak hanya pendidik dan peserta didik, tetapi juga antara peserta didik dengan konten/materi, dan juga interaksi antar peserta didik (Rice, 2006). Penerapan e-learning ditentukan oleh proporsi waktu pembelajaran yang disampaikan secara tatap muka ataukah online. Hasilnya, (Allen \& Seaman, 2013) telah mendefinisikan empat jenis pelaksanaan pembelajaran: tradisional ( $0 \%$ online), berbasis website (1-29\% online), blended/ bybrid (30-79\% online), dan full online (> 80\% online). Penelitian di bidang pendidikan online dan jarak jauh telah memberikan wawasan tentang kualitas dinamis dari pengajaran dan pembelajaran di lingkungan online (Barbour, 2010). Secara khusus, para praktisi pendidikan telah menganjurkan praktik pedagogis dalam pembelajaran online yang berfokus pada pendekatan konstruktivisme yang berpusat pada peserta didik (Rice, 2006) yang mempromosikan lingkungan interaktif dan pengalaman belajar yang relevan/otentik (Beldarrain, 2008).

Banyak faktor yang harus disiapkan oleh dosen dalam menerapkan e-learning dalam proses perkuliahan, selain media pembelajaran yang akan digunakan dalam memberikan materi perkuliahan, teknik evaluasi juga harus diperhatikan. Meskipun Faslah \& Santoso (2017) berpendapat bahwa mahasiswa dan dosen sudah siap untuk e-learning diterapkan dalam pembelajaran, tetapi masih diperlukan perbaikan pada beberapa faktor. Hal ini dapat diatasi dengan menggunakan teknologi seperti presentasi Power Point, video digital, dan presentasi multimedia. Sehingga dosen dapat menerapkan evaluasi berbasis kinerja. Ukuran kelas (banyaknya mahasiswa dalam satu kelas) juga harus dipertimbangkan saat merencanakan penilaian. Kelas yang besar membutuhkan banyak waktu untuk dosen dalam menilai. Dosen akan membutuhkan lebih banyak waktu untuk menilai jika kelasnya terlalu besar.

Sebagian besar studi yang disebutkan menunjukkan bahwa pada umumnya mahasiswa memiliki persepsi positif terhadap pembelajaran online (Burac, Fernandez, Cruz, \& Cruz, 2019), meskipun mereka terkadang menghadapi masalah teknis dan menganggap bahwa mereka memproses informasi dengan lebih baik apabila melaksanakan pembelajaran secara tradisional (tatap muka) (Alsaaty, Carter, Abrahams, \& Alshameri, 2016). Selain itu, penelitian lain mengungkapkan beberapa manfaat pembelajaran online seperti penyesuaian perkuliahan dengan kebutuhan mahasiswa (Babu \& Sridevi, 2018), keterpusatan kepada mahasiswa (Al-Dosari, 2011), dan menghilangkan hambatan ruang dan waktu, serta hal-hal yang memotivasi mahasiswa untuk bergabung dalam video conference dan bertukar pendapat (Arkorful \& Abaidoo, 2014).

\section{Simpulan dan Rekomendasi}

Berdasarkan hasil penelitian, beberapa temuan penting terkait dengan penerapan e-learning yang sudah diterapkan kepada mahasiswa. Pertama, dosen harus melihat motivasi mahasiswa dalam mengikuti kuliah online, meskipun sulit karena tidak ada kontak secara langsung, namun tetap harus dilakukan dengan cara memberikan formulir secara online untuk mengetahui tingkat motivasi mahasiswa dalam melakukan pembelajaran secara online. Dari informasi yang diperoleh, seorang dosen dapat mengidentifikasi sejumlah strategi untuk melibatkan mahasiswa dan membuat mereka tetap termotivasi dalam melakukan pembelajaran secara online. Yang terpenting, perlu dicatat bahwa lebih banyak teknologi yang digunakan tidak selalu menghasilkan hasil pembelajaran yang lebih baik. Dosen yang mengajar harus diwawancarai untuk mendapatkan umpan balik guna mengevaluasi pelaksanaan e-learning dari perspektif dosen. Pertanyaan wawancara harus fokus pada evaluasi elearning dan implikasi untuk meningkatkan kualitas pembelajaran melalui e-learning. Ditambah dengan mahasiswa terbiasa melakukan praktek di lapangan sebagai calon guru pendidikan jasmani. Perubahan paradigma pembelajaran yang terjadi sangat signifikan, metode pembelajaran baru telah diterapkan, sehingga dosen dan mahasiswa perlu mengikuti perkembangan yang terjadi, tidak hanya dalam keterampilan mengajar dan perkembangan keilmuannya, tetapi juga teknologi. Dosen dan mahasiswa jaman sekarang cenderung takut dengan perubahan dan hal-hal yang baru. Menerapkan elearning dalam perkuliahan pada Prodi Penjaskesrek, FKIP, Universitas Sriwijaya adalah bagian penting dari pembelajaran keseluruhan yang dapat menjangkau banyak orang. Namun, penelitian terkait dengan penerapan e-learning pada program studi keolahragaan masih dalam tahap awal. Masih 
banyak pekerjaan yang harus dilakukan untuk memberikan jawaban nyata, misalkan dengan meneliti terkait dengan faktor gender, sosial, dan ekonomi mahasiswa yang menjalankan pembelajaran dengan sistem e-learning. Sebuah kenyataan yang harus diakui bahwa penelitian lebih lanjut yang akan dilakukan untuk menilai pengaruh penerapan e-learning pada program studi keolahragaan sangat diperlukan untuk meningkatkan dan memperkuat sistem e-learning.

\section{Ucapan Terima Kasih:}

Terima kasih kepada civitas akademik Program Studi Pendidikan Jasmani, Kesehatan, dan Rekreasi, FKIP, Universitas Sriwijaya yang telah berkenan mengisi kuisioner dalam penelitian ini.

\section{Daftar Pustaka:}

Aboagye, E., Yawson, J. A., \& Appiah, K. N. (2021). COVID-19 and E-Learning: the Challenges of Students in Tertiary Institutions. Social Education Research, 2(1), 1-8. https://doi.org/10.37256/ser.212021422

Adnan, M., \& Anwar, K. (2020). Online learning amid the COVID-19 pandemic: students' perspectives. Journal of Pedagogical Sociology and Psychology, 2(1), 45-51. https://doi.org/10.33902/JPSP

Al-Dosari, H. (2011). Faculty members and students perceptions of e-learning in the English Department: a project evaluation. Joumal of Social Sciences, 7(3), 391-407. https://doi.org/10.3844/jssp.2011.391.407

Allen, I. E., \& Seaman, J. (2013). Changing Course: Ten Years of Tracking Online Education in the United States, Sloan Consortium (NJ1), 2013-Jan.

Alsaaty, F. M., Carter, E., Abrahams, D., \& Alshameri, F. (2016). Traditional versus online learning in institutions of higher education: minority business students' perceptions. Business and Management Research, 5(2), 41. https://doi.org/10.5430/bmr.v5n2p31

Arkorful, V., \& Abaidoo, N. (2014). The role of e-learning, the advantages and disadvantages of its adoption in Higher Education. International Journal of Education and Research, 2(12).

Babu, G. S., \& Sridevi, K. (2018). Importance of e-learning in Higher Education: a study. International Journal of Research Culture Society, 2(5), 84-88.

Barbour, M. (2010). Researching K-12 Online Learning: What Do We Know and What Should We Examine? Education Faculty Publications, 7(2), 7-12.

Beldarrain, Y. (2008). Engaging the 21st century learner: An exploratory study of the relationship between interaction and achievement in the virtual high school. Capella University, Minneapolis, Minn, USA.

Brewer, J. D. (2001). The Impact of a Web-based versus Face-to-Face Instructional Format of a Lifetime Fitness Course on Students' Wellness Knowledge, Attitudes and Behaviors and Levels of Health-Related Physical Fitness. Kansas State University, Manhattan, Kan, USA.

Burac, M. A. P., Fernandez, J. M., Cruz, M. M. A., \& Cruz, J. Dela. (2019). Assessing the impact of elearning system of higher education institution's instructors and students. IOP Conference Series: Materials Science and Engineering, 482(1), 012009. Institute of Physics Publishing. https://doi.org/10.1088/1757-899X/482/1/012009 
Cardinal, B. J. (2012). How can we help college and university students stay active and healthy for life? Journal of Physical Education, Recreation \& Dance, 83(8), 53-53. https://doi.org/10.1080/07303084.2012.10598831

Cheung, C., \& Cable, J. (2017). Eight principles of effective online teaching. PM W orld Journal: A Global Resource for Sharing Knowledge in Program and Project Management, VI(7), 1-22.

Daum, D. N., \& Buschner, C. (2012). The status of high school online physical education in the United States. Journal of Teaching in Physical Education, 31(1), 86-100. https://doi.org/10.1123/jtpe.31.1.86

Daum, D. N., \& Buschner, C. (2014). Research on Teaching Blended and Online Physical Education. In Ri. E. Ferdig \& K. Kennedy (Eds.), Handbook of Research on K-12 Online and Blended Learning (pp. 201-221). Pittsburgh, Pa, USA: ETC Press.

Dhawan, S. (2020). Online learning: a panacea in the time of COVID-19 crisis. Journal of Educational Technology Systems, 49(1), 5-22. https://doi.org/10.1177/0047239520934018

El-Seoud, M. S. A., Taj-Eddin, I. A. T. F., Seddiek, N., El-Khouly, M. M., \& Nosseir, A. (2014). Elearning and students' motivation: a research study on the effect of e-learning on higher education. International Journal of Emerging Technologies in Learning (IJET), 9(4), 20-26. https://doi.org/10.3991/ijet.v9i4.3465

Faslah, R., \& Santoso, H. B. (2017). Analisis kesiapan implementasi e-learning menggunakan elearning readiness model. POSITIF: Jurnal Sistem Dan Teknologi Informasi, 3(2), 120. https://doi.org/10.31961/positif.v3i2.431

Firman, \& Rahman, S. R. (2020). Pembelajaran Online di Tengah Pandemi Covid-19. Indonesian Journal of Educational Science (IJES), 2(2).

Galy, E., Downey, C., \& Johnson, J. (2011). The effect of using e-learning tools in online and campusbased classrooms on student performance. Journal of Information Technology Education, 10, 209-230.

Gibbone, A., \& Mercier, K. (2014). Accomplishing PETE learning standards and program accreditation through teacher candidates' technology-based service learning projects. Journal of Physical Education, Recreation \& Dance, 85(5), 18-22. https://doi.org/10.1080/07303084.2014.897568

Goad, T., Jones, E., Bulger, S., Daum, D., Hollett, N., \& Elliott, E. (2021). Predicting student success in online physical education. American Journal of Distance Education, 35(1), 17-32. https://doi.org/10.1080/08923647.2020.1829254

Guan, B. (2012). Determination of China's online physical education object. Procedia Engineering, 29, 3557-3561. Elsevier. https://doi.org/10.1016/j.proeng.2012.01.530

Harris, M. T., \& Metzler, M. (2018). Online personal fitness course alignment with national guidelines for online physical education. Journal of Teaching in Physical Education, 38(3), 1-13. https://doi.org/10.1123/jtpe.2018-0169

Indrayana, B., \& Sadikin, A. (2020). Penerapan e-learning di era revolusi industri 4.0 untuk menekan penyebaran Covid-19. Indonesian Journal of Sport Science and Coaching, 2(1), 46-55. https://doi.org/10.22437/ijssc.v2i1.9847

Juniu, S. (2011). Pedagogical uses of technology in physical education. Journal of Physical Education, 
Recreation \& Dance, 82(9), 41-49. https://doi.org/10.1080/07303084.2011.10598692

Kemdikbud. (2021a, March). PDDikti - Pangkalan Data Pendidikan Tinggi.

Kemdikbud. (2021b, March). Rekap Data Pokok Pendidikan Nasional.

Kennedy, K., \& Archambault, L. (2012). Offering preservice teachers field experiences in K-12 online learning: a national survey of teacher education programs . Journal of Teacher Education, 63(3), 185200. https://doi.org/10.1177/0022487111433651

Mohnsen, B. (2012). Implementing online physical education. Journal of Physical Education, Recreation \& Dance, 83(2), 42-47. https://doi.org/10.1080/07303084.2012.10598727

Mooneyhan, A. (2012). Using the internet as a supplemental delivery method on University Concepts of fitness classes. International Journal on E-Learning, 11(2), 181-187.

Mosier, B., \& Lynn, S. (2012). An initial exploration of a virtual personal fitness course. Online Journal of Distance Learning Administration, 15(3), 1-11.

Popovici, A., \& Mironov, C. (2015). Students' perception on using elearning technologies. Procedia Social and Behavioral Sciences, 180, 1514-1519. https://doi.org/10.1016/j.sbspro.2015.02.300

Rice, K. L. (2006). A comprehensive look at distance education in the K-12 context, Journal of Research on Technology in Education, 2006. Journal of Research on Technology in Education, 38(4), 425-448.

Saifuddin, M. F. (2018). E-Learning dalam Persepsi Mahasiswa. Jurnal V ARIDIKA, 29(2), 102-109. https://doi.org/10.23917/varidika.v29i2.5637

Sangrà, A., Vlachopoulos, D., \& Cabrera, N. (2012). Building an inclusive definition of e-learning: an approach to the conceptual framework. International Review of Research in Open and Distance Learning, 13(2), 145-159. https://doi.org/10.19173/irrodl.v13i2.1161

SHAPE. (2016). SHAPE of The Nation ${ }^{T M}$ : Status of Physical Education in the USA. Annapolis Junction.

Sun, L., Tang, Y., \& Zuo, W. (2020). Coronavirus pushes education online. Nature Materials, 19(6), 687. https://doi.org/10.1038/s41563-020-0678-8

Suresh, M., Vishnu Priya, V., \& Gayathri, R. (2018). Effect of e-learning on academic performance of undergraduate students. Drug Invention Today |, 10, 1797-1800.

Tagoe, M. (2012). Students' perceptions on incorporating e-learning into teaching and learning at the University of Ghana. International Journal of Education and Development Using Information and Communication Technology (IJEDICT), 8(1), 91-103.

Williams, L. (2013). A Case Study of Virtual Physical Education Teachers' Experiences in and Perspectives of Online Teaching. University of South Florida.

Williams, L., Martinasek, M., Carone, K., \& Sanders, S. (2020). High school students' perceptions of traditional and online health and physical education courses. Journal of School Health, 90(3), 234 244. https://doi.org/10.1111/josh.12865

Yodha, S. A., Abidin, Z., \& Adi, E. P. (2019). Persepsi mahasiswa terhadap pelaksanaan e-learning dalam mata kuliah manajemen sistem informasi mahasiswa Jurusan Teknologi Pendidikan 
Universitas Negeri Malang. Jurnal Kajian Teknologi Pendidikan, 2(3), 181-187. https://doi.org/10.17977/um038v2i32019p181

Yusuf, N., \& Al-Banawi, N. (2013). The impact of changing technology: the case of e-learning. $\begin{array}{lllll}\text { Contemporary Issues in Education Research (CIER), } & 6(2), & 180 .\end{array}$ https://doi.org/10.19030/cier.v6i2.7726 